\title{
MANAGEMENT OF MAJOR HEPATIC RESECTION \\ IN INFANTS AND CHILDREN \\ REPORT OF SIXTEEN CASES
}

\author{
Yvon Turmel, M.D., S. Moussa, M.D., AND H. Blanchard, M.D. *
}

EXTENSTE HEPATECTOMY has always been a challenge to both the surgeon and the anaesthetist. Even today, peroperative and post-operative mortality is as high as 30 per cent to 40 per cent. ${ }^{5-7}$ Although the surgical techniques have been greatly improved by Quattlebaum, ${ }^{1}$ Pack, ${ }^{2}$ McDermott, ${ }^{3}$ Longmire ${ }^{4}$ and others, the operative complications remain numerous. Sudden, massive and uncontrollable haemorrhage ${ }^{5,6,8,9}$ is the most serious of these and sometimes is fatal. As the blood volume of the neonate, the infant and the child is small, blood loss may easily be under-rated or over-estimated; in either case, the consequences could be serious.

At Ste. Justine Hospital for children in Montreal (S.J.H.M.) 16 patients had major hepatic resections between 1965 and 1972. These cases will be presented. Preoperative evaluation and operative management will be reviewed and some of the early post-operative complications will be summarized.

In our series there were seven females and nine males. Their ages ranged from 14 days to 13 years and their weight from 2.3 to $48 \mathrm{~kg}$. Their expected blood volumes varied from $184 \mathrm{ml}$ to $3840 \mathrm{ml}$, based on an average of $80 \mathrm{ml} / \mathrm{kg}$ of body weight for all age groups.

There were eleven cases of hepatic tumour and five post-traumatic hepatic lacerations. Twelve had resection of the right hepatic lobe, and four of the left.

The anaesthetic agents were halothane in ten cases, droperidol or narcotics in four cases, methoxyflurane in one case and oxygen only in one patient who was comatose.

Moderate hypothermia (between $29^{\circ} \mathrm{C}$ and $33^{\circ} \mathrm{C}$ ) was used during operation on nine occasions. The average age in this group was 3 years and 10 months and the average operating time was 7 hours and 30 minutes.

The other seven patients were operated upon without hypothermia; their average age was 7 years and 3 months, and the average operating time was 4 hours and 25 minutes.

\section{Results}

1. Mortality: Four of the sixteen patients died, for an average mortality of 25 per cent. Brief details of these cases follow.

(a) J.C. (77-24-00) a seven-year-old - weighing $25 \mathrm{~kg}$ - brought to the opera-

"From the Departments of Anesthesiology and Surgery, Ste. Justine Hospital, University of Montreal, Montreal, Canada. 
TABLE I

\begin{tabular}{|c|c|c|c|c|}
\hline \multicolumn{5}{|l|}{ Indication for Hepatic Resection } \\
\hline \multirow{2}{*}{\multicolumn{2}{|c|}{ A. Hepatic tumour }} & $\begin{array}{c}\text { Total } \\
11\end{array}$ & $\begin{array}{c}\text { Death } \\
1\end{array}$ & $\begin{array}{c}\% \text { Mortality } \\
9\end{array}$ \\
\hline & & & & \\
\hline \multicolumn{5}{|l|}{ Hepatocarcinoma (3) } \\
\hline \multicolumn{5}{|l|}{ Haemangioma (2) } \\
\hline \multicolumn{5}{|l|}{ Metastatic (3) } \\
\hline \multicolumn{5}{|l|}{ Rhabdomyosarcoma (1) } \\
\hline B. Hepatic trauma & & 5 & 3 & 60 \\
\hline \multicolumn{5}{|l|}{ Extent of Liver Resection } \\
\hline Right lobectomy (12) & $\underset{5}{\text { Trauma }}$ & $\underset{7}{\text { Tumour }}$ & $\begin{array}{c}\text { Death } \\
4\end{array}$ & $\begin{array}{c}\% \text { Mortality } \\
33\end{array}$ \\
\hline Left lobectomy (4) & 0 & 4 & 0 & 0 \\
\hline \multicolumn{5}{|l|}{ Influence of hypothermia } \\
\hline Hypothermia $(9)$ & Trauma & Tumour & Death & $\%$ Mortality \\
\hline without Hypothermia (7) & 3 & 4 & 3 & 43 \\
\hline
\end{tabular}

ting room in shock from multiple trauma. An exploratory laparotomy was done and an attempt was made to resect the right hepatic lobe. The patient received $10,000 \mathrm{ml}$ of blood, representing five times his blood volume. Death was confirmed 1.45 hours after the beginning of the operation. At the autopsy, a laceration of the right pulmonary hilum with haemothorax and laceration of the kidneys accompanied by retro-peritoneal haemorrhage were found as well as a fracture of the right femur.

(b) C.C. (68-18-34) a 3-year-old with multiple trauma, weighing $13 \mathrm{~kg}$, had right hepatectomy and splenectomy. He received $3,500 \mathrm{ml}$ of blood representing 3.3 times his blood volume. Following two cardiac arrests, it was noted that his blood coagulability was unsatisfactory and he died 30 minutes after the end of the operation. At the autopsy, fractures of the right femur and the fifth right rib were also noted.

(c) A.D. (60-25-41), a 10-year-old weighing $30 \mathrm{~kg}$ was operated on for hepatic laceration following a fall. Liver haemostatis was achieved with suture and packing. Twenty days later, he was reoperated for hepatic haematoma which was incised and drained.

Twenty-seven days after the last operation, gastrointestinal haemorrhages occurred and a negative exploratory laparotomy was followed by a gastrostomy. Two days later, the child was still bleeding from the gastrointestinal tract and was found to have haemobilia. A right hepatectomy was carried out. During dissection of the hepatic veins massive bleeding occurred and the child died on the table. He had received $6,000 \mathrm{ml}$ of blood or about 2.5 times his blood volume.

(d) M.L. (65-84-77), a 15-month-old child weighing $12 \mathrm{~kg}$ with a malignant hepatoma underwent a right hepatectomy under hypothermia of $88^{\circ} \mathrm{F}$. He had three cardiac arrests and died on the table after 8 hours and 50 minutes of operation. He received $900 \mathrm{ml}$ of blood, about equal to his blood volume.

Of the four deaths, only one patient was under hypothermia. Three deaths occurred in patients with trauma and one in a patient with a malignancy.

2. Blood Loss: Average blood loss during the operation was about 2.2 times the estimated blood volume. 
The average loss for a left hepatic lobectomy was 1.4 times the estimated blood volume and for a right lobectomy about 2.5 times. For a traumatic hepatic rupture, average loss was 3.5 times the estimated blood volume and for a hepatic tumour it was about 1.7 times.

There was no difference between the losses under normothermia and hypothermia. In both cases the average blood losses were 2.2 times the estimated blood volume.

3. In our series we had two cases of haemobilia, one of whom survived. ${ }^{42}$ Two of the five trauma cases were under hypothermia and survived (40 per cent survival).

Only one of the nine patients operated upon under hypothermia died ( 89 per cent survival). Three of the seven patients who were not under hypothermia died ( 43 per cent mortality).

\section{Preoperative Evaluation}

(a) A history and physical examination are essential but may be difficult to obtain in newborns and infants.

(b) Usually hepatic function ${ }^{6}$ (as measured by transaminase, lactic dehydrogenase, alkaline phosphatase, serum electrophoresis, prothrombin time etc.) was not altered significantly. However, liver function studies served as a baseline for evaluation of hepatic function after resection. The measurement of catecholamines and cystothionine in the urine is of more diagnostic value in the evaluation of a mass in the liver of a child. Urinary catecholamines, and especially vanylmandelic acid (VMA) are often elevated in cases of neuroblastoma, which is a common metastatic liver tumour in children. ${ }^{10-11}$ Cystothionuria has been found in children with hepatoblastoma. ${ }^{12}$

(c) Liver Biopsy: In elective cases liver biopsy provides an acurate diagnosis.

(d) Radiologic studies (pulmonary, bones, pyelography, cholangiography, etc.) are important in the preoperative evaluation. More precise evaluation may be obtained with the following procedures:

(i) Radioactive liver scanning, which may reveal the presence, site and extent of the hepatic lesion.

(ii) Inferior vena cavography and if possible supra-hepatic venography: (a) In the case of tumours, the cavography may reveal inferior vena caval occlusion, which may be due to compression or invasion.

(b) In trauma patients, these investigations may show involvement of the supra-hepatic veins and/or the inferior vena cava (e.g. laceration or rupture).

(iii) Abdominal aortography ${ }^{14,15,20}$ is invaluable in revealing, localizing, and delineating the lesion and its blood supply.

\section{Operative Management and Complications}

A. Preparations for the operation are of such importance that they may mean the difference between success and failure. Equipment and material which must be in readiness comprise: 
CANADIAN ANAESTHETISTS' SOCIETY JOURNAL

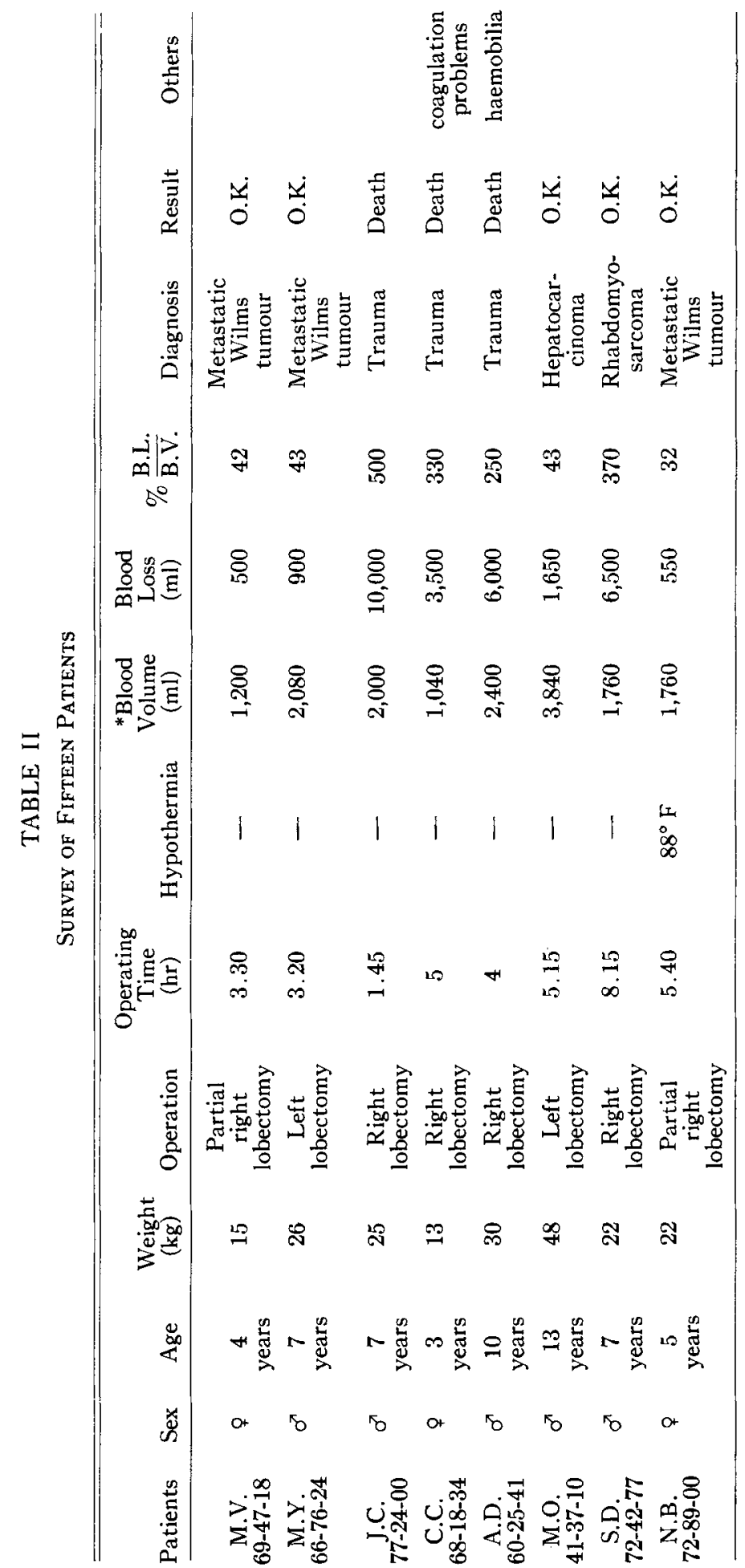


TURMEL, et al: : MANAGEMENT OF MAJOR HEPATIC RESECTION

|

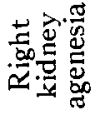

节

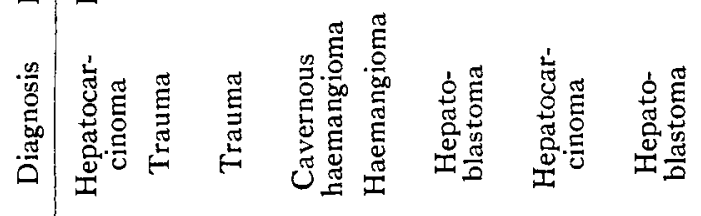

血闹

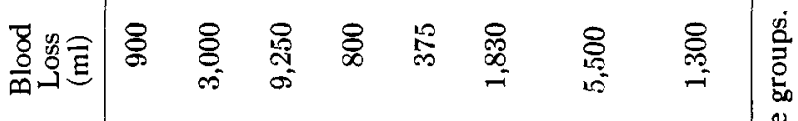

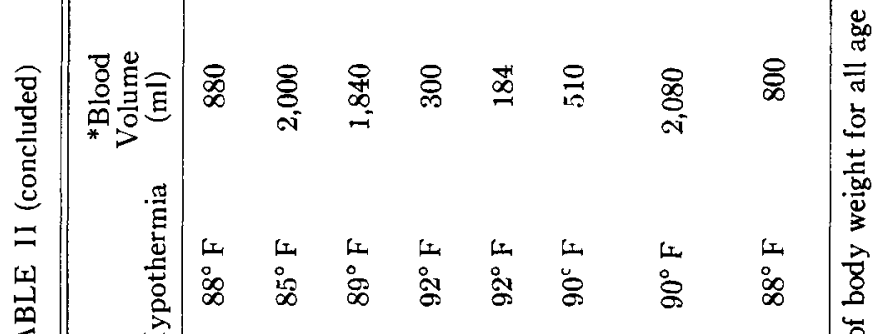

要

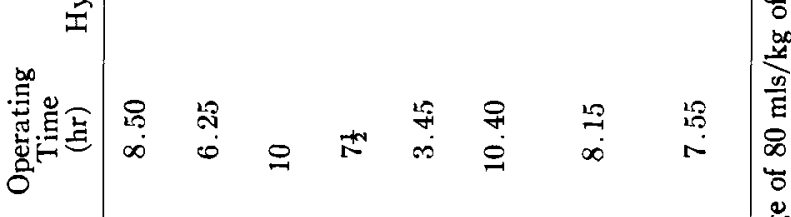

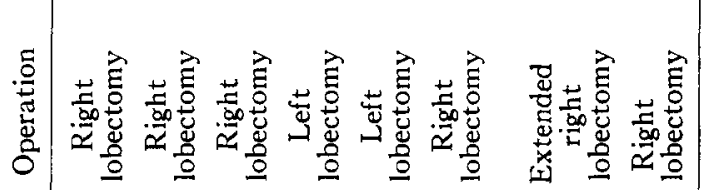

雚官

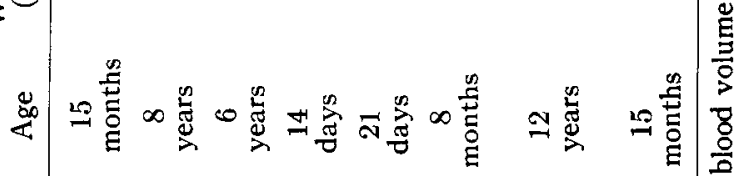

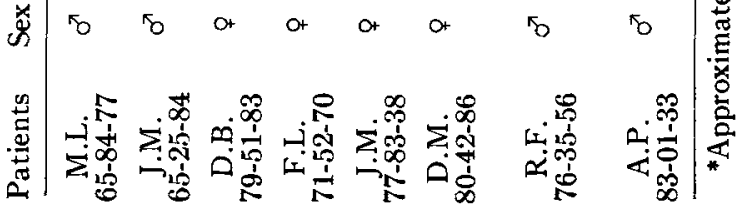


1. A tracheal tube of appropriate size which will remain in situ for up to $\mathbf{1 5}$ hours or longer.

2. A mechanical ventilator (volume cycled e.g. Engström) with humidification of inspired gases.

3. Fresh ACD blood collected the same day in large quantities (about twice the estimated blood volume) and equipment to warm the blood rapidly prior to administration.

4. A temperature controlled mattress to warm or cool the patient.

5. Arterial canula (radial) for continuous pressure monitoring and sampling for blood gases, blood sugar, haemoglobin, haematocrit, platelets, electrolytes, etc.

6. Facilities for central venous pressure monitoring (C.V.P.).

7. A second secure intravenous catheter in an upper limb for rapid blood administration (the lower limb is to be avoided because of clamping or possible laceration of the inferior vena cava).

8. Placement of a urinary catheter to avoid urinary bladder distention, ${ }^{50-52}$ and to monitor tissue perfusion.

9. A naso-gastric tube.

10. An oesophageal stethoscope.

11. An oesophageal and/or rectal telethermometer.

12. A cardioscope.

13. A defibrillator.

14. An infra-red lamp, which is helpful if rapid rewarming is required.

15. The following drugs: isoproterenol, epinephrine, sodium bicarbonate, digitalis, 2 per cent lidocaine, epsilon aminocaproic acid, 50 per cent glucose, calcium gluconate, vitamin $\mathrm{K}$, and a sufficient number of syringes and needles of all sizes.

In our series, the four deaths were associated with deficiencies in the requirements.

B. Anaesthetic management: For the elective cases, meperidine $(1 \mathrm{mg} / \mathrm{kg}$ ) and atropine $(0.01 \mathrm{mg} / \mathrm{kg})$ are given intramuscularly one hour before the operation.

The induction is started with intravenous administration of sodium thiopentone ( 3 to $5 \mathrm{mg} / \mathrm{kg}$ ); succinylcholine chloride $(1 \mathrm{mg} / \mathrm{kg}$ ) is ordinarily given to facilitate the intubation.

For maintenance of anaesthesia, we believe that halothane is a satisfactory agent for this kind of operation, even though some authors have stressed that the use of this agent cannot be recommended in conditions associated with hepatic involvement. ${ }^{16-17-18}$ Halothane has some well known advantages. One of these is the peripheral vasodilatation which assists in the induction of hypothermia. Another is that halothane is largely and rapidly eliminated when its administration is stopped, which can be of help in cardiac arrest. For elective cases where haemorrhage is usually less dramatic we prefer intravenous agents such as Innovar.

Gallamine is excreted unchanged in the urine, and is recommended as the muscle relaxant for these patients.

C. Hypothermia: ${ }^{19}$ In spite of the increased hazard of myocardial irritability in 
infants, with consequent ventricular fibrillation, hypothermia may be beneficial in reducing the metabolic rate and thus providing some protection to the liver. Ischaemia of the remaining liver tissue may occur because of manipulation, stasis and kinking of the hepatic pedicle or of the inferior vena cava. Moreover, hypothermia will allow a longer clamping time of the hepatic pedicle if that should become necessary. ${ }^{21,22}$ It also affords some protection to hepatic and cerebral cells in the event of circulatory failure. ${ }^{23,25,30}$ Of our nine hypothermia cases, one died, and many of the survivors had cardiac arrests varying from 30 seconds to 30 minutes. None had neurological or other sequelae. Hypothermia also diminishes the concentrations of anaesthetic agents required, beneficial since the majority (both inhalational and intravenous) are detoxified by or have noxious effects on the liver.

In view of the disturbed hepatic glycogenolysis, hypothermia protects against the neurological sequelae of hypoglycaemia by reducing cellular metabolism and the liberation of insulin. Usually a 5 per cent glucose infusion will maintain a serum blood sugar level of $200 \mathrm{mg}$ or more, depending on the rate of administration.

In the light of these nine cases and others, we conclude that generally infants and children tolerate temperatures below $30^{\circ} \mathrm{C}$ poorly. At temperatures of less than $30^{\circ} \mathrm{C}$ any insult, such as sudden haemorrhage, could precipitate a cardiac arrythmia or even fibrillation. Therefore it is preferable to avoid temperatures below $30^{\circ} \mathrm{C}$.

D. Massive Haemorrhage: Sudden, massive and uncontrollable haemorrhage constitutes one of the most fearsome and sometimes fatal complications. ${ }^{6,9,27}$ It usually occurs when dissection is being carried out around the hepatic veins near the inferior vena cava. The child may lose twice his blood volume. Enough fresh ACD blood warmed to body temperature before administration $^{13}$ should be available. Children tolerate fresh warm ACD blood well. Yet it must be mentioned that some authors believe that children tolerate heparinized blood better. Considering the small blood volume of the newborn and infant it is easy to over-estimate or under-estimate blood losses, with serious outcome in either case.

Taylor $^{6}$ notes in his series one death because the blood administration catheter was in a hepatic vein; that is, in the operative field.

During massive haemorrhage, the best indices are the C.V.P., continuous arterial pressure monitoring and the appearance of the liver; the cardioscope and the oesophageal stethoscope are good secondary monitors.

E. Air or tissue emboli: Air $^{24-26}$ or tissue emboli ${ }^{41}$ have caused some operative deaths. Due to the subatmospheric thoracic pressure and the velocity of blood flow, air and/or tissue may be sucked into an open vessel. Quattlebaum, ${ }^{1}$ Pack, ${ }^{2}$ McDermott ${ }^{3}$ and others recommend a thoracoabdominal incision to minimize this hazard. This approach was used in our series, especially for right hepatic lobe resection.

F. Hypoglycaemia: $:^{3,28,29}$ Hypoglycaemia may supervene during operation and have serious neurological sequelae. One of the functions of the liver is to maintain normoglycaemia. Major hepatic resections impair the ability of the 
liver to perform this function to a degree and for a period of time proportionate to the amount of normal parenchyma excised. Hypothermia and a 5 per cent glucose infusion are satisfactory safeguards. However, if no hypothermia is used, a 10 per cent glucose infusion would be safer. It is advisable to check blood glucose concentration at intervals, especially when clamping of the hepatic pedicle is necessary. Hyperkalaemia ${ }^{53}$ and acidosis ${ }^{54}$ occur following release of hepatic pedicle occlusion.

G. Blood Sequestration in the Splanchnic Bed: Blood sequestration in the splanchnic bed following extensive hepatectomy may reach 60 per cent of the blood volume. ${ }^{7}$ This is due to a reduction in the number of vessels draining the liver and the portal bed. Following a minor resection the alterations are minimal. However, with a larger resection, all the splanchnic area will have to drain through the remaining hepatic lobe, leading to increased pressure in the portal bed. At the same time the residual liver becomes passively engorged. To prevent peripheral hypovolaemic shock, additional volumes of blood or some other colloid must be administered. The central venous pressure is the only accurate guide since blood volume determinations are seldom reliable under these circumstances.

This relative hepatic venous obstruction may persist for several days while a gradual dilatation of the residual hepatic veins takes place.

H. Coagulation Problems: The large quantity of ACD blood transfused and damage to liver parenchymal may cause bleeding problems. The insult to the hepatic parenchyma may activate the fibrinolytic system ${ }^{47}$ which will exhaust fibrinogen, prothrombin, and factors V, VII, IX, and X. Epsilon-amino-caproic acid (Amicar) given intravenously and as a 1 per cent solution for irrigation of the sectioned part of the liver, ${ }^{31-35}$ and rapid termination of the procedure may remedy the condition.

Warm fresh blood will avoid the problems of massive stored blood transfusions (acidosis, hypocalcaemia, hyperkalaemia, thrombocytopenia, hypofibrinogenaemia, reduction of 2, $3 \mathrm{DPG}$, etc.).

While calcium administration with massive blood transfusion remains controversial, ${ }^{36-39}$ it nevertheless is our policy to administrate calcium gluconate, $100 \mathrm{mg}$ for each 150 to $200 \mathrm{ml}$ of blood given.

Blood samples for $\mathrm{Ca}^{+}, \mathrm{K}^{+}$, glucose, platelets, prothrombin and fibrinogen should be obtained at regular intervals.

In elective cases, we recommend the administration of vitamin $\mathrm{K}$ for two days prior to operation.

\section{Immediate Post-Operative Management}

A. Ventilation: These patients are candidates for post-operative atelectasis because of the large thoraco-abdominal incision. The right side is usually involved, but Quattlebaum ${ }^{40}$ reports a left atelectasis with death. We therefore recommend mechanical ventilation with humidified air for about 5 hours in the immediate post-operative period with periodic over-inflation of the lungs to prevent miliary atelectasis. 
B. Rewarming should be slow if hypothermia was used. Usually there is no shivering on rewarming but should it happen, meperidine and promethazine is the treatment of choice.

C. Extubation: It is advisable to give steroids prior to extubation to minimize subglottic oedema, and to keep the patient in a high humidity atmosphere thereafter.

D. Central Venous Pressure: C.V.P. is a good means of detecting splanchnic pooling ${ }^{50}$ and haemorrhage.

E. Arterial blood gases: $\mathrm{PO}_{2}, \mathrm{Pco}_{2}$ and $\mathrm{pH}$ should be followed for control of acid-base balance.

F. Maintenance of blood sugar: During the first few days and sometimes for longer periods the blood glucose level is unstable, with a tendency towards hypoglycaemia, requiring 10 per cent or 20 per cent glucose infusion, $, 3,6$ to maintain normoglycaemia.

G. Serum albumin: Alburnin production occurs only in the liver. ${ }^{749}$ After the excision of large amounts of hepatic parenchyma, there is a failure to replenish albumin losses adequately. Thus it is necessary to give albumin to prevent hypoalbuminaemia. In patients who have undergone major hepatic resection, the combination of hypoalbuminaemia and portal hypertension may produce an almost unmanageable ascites. ${ }^{7}$

$H$. It is necessary to give vitamin $K$ supplement and to assess urinary output and serum electrolytes.

\section{Major Post-Operative Complications}

Major post-operative complications may be tabulated as follows:

1. Haemorrhage $e^{5,20}$ and splanchnic sequestration of blood may result in hypotension and possibly shock.

2. Pulmonary complications, atelectasis, pleural effusion, pneumonia, pneumothorax, right diaphragmatic paresis, all with consequent hypoventilation.

3. Subphrenic abscess. ${ }^{5,27,42}$

4. Biliary fistula.

5. Stress ulcer. ${ }^{27}$

6. Ascites.

7. Jaundice. ${ }^{45}$

8. Hypoglycaemia. ${ }^{3,6,7}$

9. Infectious mononucleosis ${ }^{43,44, D \cdot B, *}$ and post-transfusion hepatitis. ${ }^{46}$

10. Hypoalbuminaemia. ${ }^{48}$

11. Septicaemia. ${ }^{42}$

12. Organ failure: Liver-Kidney. ${ }^{27}$

\section{SUMMARY}

Sixteen extensive hepatectomies were performed at Ste. Justine Hospital for Children in Montreal from 1965 to 1972. Of these, five patients presented with massive trauma and eleven with primary or secondary tumour of the liver. There 
were four operative deaths ( 25 per cent mortality), three due to trauma and one due to a hepatic tumour.

Nine patients were operated upon under mild hypothermia $\left(29^{\circ}-33^{\circ} \mathrm{C}\right)$ with one death ( 11 per cent mortality). Of the seven children without hypothermia, three died ( 43 per cent mortality).

Blood losses averaged 2.2 times estimated blood volume in all patients, while blood losses for the trauma cases averaged 3.5 times the estimated blood volume.

${ }^{*}$ D.B. (79-51-83) had infectious mononucleosis.

Generic and Trade Names of drugs

Halothane
Meperidine
Methoxyflurane
Lidocaine
Digitalis
d-tubocurarine
Gallamine
Epinephrine
Isoproterenol
Epsilon amino caproic acid
Promethazine
Droperidol
Fentanyl
Droperidol
Fentanyl

\section{Halothane}

Meperidine

Methoxyfurane

d-tubocurarine

Gallamine

Epinephrine

Epsilon amino caproic acid

Promethazine

Droperido

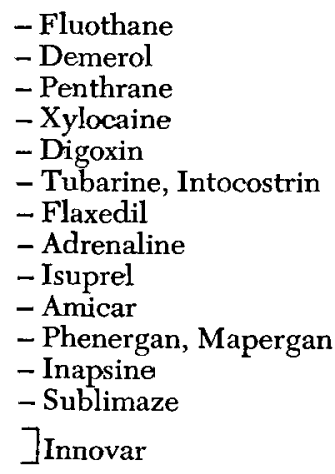

\section{RÉSUMÉ}

Seize résections hépatiques extensives ont été pratiquées à l'hôpital Ste-Justine de Montréal, de 1965 à 1972. Quatre décès sont survenus durant les interventions (soit 25 pour cent de mortalité). Trois de ces décès étaient dus à des traumatismes tandis que l'autre avait pour cause une tumeur hépatique.

Neuf patients furent opérés sous hypothermie entre $29^{\circ}$ et $33^{\circ} \mathrm{C}$. De ces neuf patients, un seul est décédé (soit 11 pour cent de mortalité). Sur les sept patients qui ont été opérés sans hypothermie, il y a eu trois décès (soit 43 pour cent de mortalité). Les pertes sanguines moyennes ont été de 2.2 fois le volume sanguin apprécié des enfants; les pertes sanguines moyennes pour les traumatisés abdominaux furent de 3.5 fois leur volume sanguin apprécié.

\section{ACKNOWLEDGMENT}

The authors wish to express their appreciation to Dr. F. Guttman, Miss Pauline Cirino and Miss Louise Turmel for their collaboration.

\section{REFERENCES}

1. Quattlebaum, J.K. Technic of hepatic resection. Surgery 58: 1075 (1965).

2. PACK, G.T. \& IsL.AmI, A.H. Operative treatment of hepatic tumors. Clin. Symposia 16: 35 (1964).

3. McDermotr, W.V., Jr., Greenberger, N.J., Isselbacher, K.J., \& Weber, A.L. Major hepatic resection: diagnostic techniques and metabolic problems. Surgery 54: 56 (1963).

4. Longmire, W.P. Hepatic Surgery: trauma, tumors and cysts. Ann. Surg, 161: 1 (1965). 
5. Ackroyd, F.W., Pollard, J., \& McDermott, W.V. Massive hepatic resection in the treatment of severe liver trauma. Amer. J. Surgery 117: 442-8 (April 1969).

6. TAylor, P.H., Filler, R., Nebesar, R., \& TeffT, M. Experience with hepatic resection in childhood. Amer. J. Surg. 117: 435-41 (April 1969).

7. Stone, H.H., Long, W.D., Smith, R.B., \& Haynes, C.D. Physiologic considerations in major hepatic resection. Amer. J. Surg. 117: 78-84 (January 1969).

8. Martin, L.W. \& Woodman, Ke Hepatic lobectomy for hepatoblastoma in infants and children. Arch. Surg. 98: 1-7 (1969).

9. Furman, E.B. Anesthesia for right hepatic lobectomy in a child: an exercise in blood volume management. Anesthesiology 35, No. 4: 436-38 (October 1971).

10. Voorhess, M.L. The catecholamines in tumor and urine from patients with neuroblastoma, ganglioneuroblastoma, and pheochromocytoma. J. Pediat. Surg. 3: 147 (1968).

11. Botvon, C. Catecholomine metabolism in neuroblastoma. J. Pediatr. Surg. 3: 114 ( 1968 ).

12. C Jessing, L. \& Mauritzen, K. Cystothioninuria in hepatoblastoma. Scandinav. J. Cin. d. Leb. Invest. 17: 513 (1965)

13. Boyan, C.P. \& Howland, W.S. Blood temperature: a critical factor in massive transfusions. Anesthesiology 22: 559 ( 1961 ).

14. TAwes, R.L., James, A.M., \& Hyde, G.A. Hepatic hemangioma: successful resection in a neonate. Surg. 70: 781 (1971).

15. Nebesar, R.A., Pollard, J.J., \& Stone, D.L. Angiographic diagnosis of malignant disease of the liver. Radiology, 86: 284 (1966).

16. Carney, F.M.T. \& Van Dyke, R.A. Halothane hepatitis; a critical review. Anesth. and Analg. 51, No. 1: 135-160 (Jan. and Feb. 1972).

17. Dykes, M.H.M. \& Bunker, J.P. Hepatoloxicity and anesthetics. Pharmacology for Physicians. 4: No. 11 (Nov. 1970).

18. Hege, M.J.D. Halothane anesthesia in a patient with acute hepatic disease. Anesthesiology 32: $170-171$ (1970).

19. Wylie, W.D. \& Churchill-Davioson, H.C. A practice of anaesthesia-3rd ed. Chap. 46, 1272-1295 (1972).

20. Boijsen, E., Judkins, M.P., \& Simay, A. Angiographic diagnosis of hepatic rupture. Radiology, 86: 66 (1966).

21. LongMire, W.P., Jr. \& Marable, S.A. Clinical experiences with major hepatic resections. Ann. Surg. 53: 852 ( 1966 ).

22. Raffuct, F.L. Tolerance of dogs to occlusion of the entire afferent vascular inflow to the liver. Proc. Surg. Forum, Congress, Amer. Coll. Surgeons p. 191, Philadelphia, W.B. Saunders Co. (1951).

23. Rosomoff, H.L. \& Holiday, D.A. Cerebral blood flow and cerebral oxygen consumption during hypothermia. Amer. J. Physiology 179: 85-88 (1954).

24. Payne, W.D., Terz, J.J. \& Lawrence, W. Major hepatic resection for trauma. Ann. Surg. 170: 929 (1969).

25. Rosomoff, H.L. Protective effects of hypothermia against pathological processes of the nervous system. Ann. N.Y. Acad. Sci. 80:472-475 (1959).

26. Aronsen, K.F., Bengmark, S., \& et al. Liver resection in the treatment of blunt injuries to the liver. Surgery 63: 236 (1968).

27. Pinkerton, J.A., Sawyens, J.L., \& Foster, J.H. A study of the postoperative course after hepatic lobectomy. Ann. Surg. 173, No. 5: 800-811 (May 1971).

28. Raffuci, F.L. \& Ramrez-Schon, G. Management of tumor of the liver. Sur. Gynec. and Obst. 130: $371(1970)$.

29. Aldretre, J.A. Anesthesia and intra-operative care in experience in hepatic transplantation. Starzl, T.E. et Putnam, C.W. Chap. 7, 91-92 et 98. W.B. Co., Phila., London, Toronto (1969).

30. Galindo, A. Neurosurgical anesthesia. International anesthesiology clinics. 4, No. 4: 740 (winter 1966).

31. Окамото, S. Plasmin and antiplasmin, their pathologic physiology. Keio J., Med. 8: 211 (1959).

32. Alk jaersig, N., Fletcher, A.P., \& Sherry, S. Epsilon-aminocaproic acid: an inhibitor of plasninogen activation. I. Biol. Chem. 234: 832 (1959).

33. Nusson, I.M., BJorkman, S.E., \& Anderson, L. Clinical experience with epsilon-aminocaproic acid as an antifibrinolytic agent. Acta. Med. Scand. 170: 487 (1961).

34. Back, N. \& Ambrus, J.L. Fibrinolysis in surgical bleeding. Handbook for medicine, surgery and specialties. Ed. Ulin, A.V. and Gollub, S.S., Chap. 56, pp. 399-409. McGrawHill Book Co., New York, Toronto, Sydney, London, p. 1966. 
35. Drapanas, T., Shim, W.K.T., \& Stewart, J.D. Studies of fibrinolytic activity after hepatectomy. Arch. Surg. 87: 64 (1963).

36. Graves, C.L. Blood transfusion. International anesthesiology clinics. 5, No. 4: $925-938$ (winter 1967).

37. Nakasone, N., Watkins, E., Jr., Janeway, C.A., \& Gross, R.E. Experimental studies of circulatory derangement following the massive transfusion of citrated blood. J. Lab. Clin. Med. 43: 184 (1954).

38. Howland, W.S., Schweizer, O., \& Boyan, C.P. Massive blood replacement without calcium administration. Surg. Gynec. Obstet. 118: 814 (1964)

39. Howl.AND, W.S., Jacobs, R.G, \& Goulet, A.H. An evaluation of calcium administration during rapid blood replacement. Anesth. Analg. 39: 557 ( 1960 ).

40. Quattlebaum, J.K. Discussion on paper. Drs. Pinkerton, J.A., Sawyers, J.L., \& Foster, J.H. A study of the postoperative course after hepatic lobectomy. Ann. Surg. 173, No. 5: 809 (May 1971).

41. Straus, R. Pulmonary embolism caused by liver tissue. Arch. Path. 33: 69 (1942).

42. Turmel, Y. \& Blanchard, H. Rapport d'un cas d'hémobilie traumatique. Intern. Surg. 51, No. 1: 80-86 (Jan. 1969).

43. Kapsenberg, J.G., Langenfuysen, A.C., Nreweg, H.O. \& Deiss, H. Post-transfusion mononucleosis with heterophil antibodies. Acta Med. Scand. 187: 79-82 (1970).

44. Käärïinen, L., Klemola, E., \& Paloheimo, J. Rise of cytomegalovirus antibodies in an infectious mononucleosis-like syndrome after transfusion. Brit., Med., J. 1: 1270 (1966).

45. Weinberger, H.A. \& Levbarg, M.S. Benign surgical jaundice after right hepatic lobectomy for hepatoblastoma. American J. Surg. 121:606-69 (May 1971).

46. Senior, J.R. Post-transfusion hepatitis. Gastroenterology 49: 315-20 (1965).

47. Anderson, L., Nilsson, I.M., \& Olow, B. Fibrinolytic activity in man during surgery. Thromb, Diath. Haemorrh. 7: 391 ( 1962 ).

48. Almens Jö, O. \& Bengmark, S. Changes in serum protein fractions after $20-80$ per cent liver resection in man - Especially albumin changes. Acta. Chir. Scand. 135: 311-19 (1969).

49. Mrler, L.L., Bly, C.G., Watson, M.L., \& Bale, W.F. The dominant role of the liver protein synthesis. J. Exp. Med. 94: 431-453 (1951)

50. Horwitz, L.D., KM, B.M., \& GRAy, F.D., JR. Cardiopulmonary effects of distention of the urinary bladder. Amer. Heart J. 71: 345-351 (1966).

51. Stone, H.H. Discussion on paper. Pinkerton, J.A., Sawyers, J.L., \& Foster, J.H. A study of the postoperative course after hepatic lobectomy. Ann. Surg. 173, No. 5: 810 (May 1971).

52. Nicholson, M.J. Urinary bladder distenstion: A cause of hypertension during anesthesia. Anesth. Analg. 50, No. 5: 794 (1971).

53. Hall, R.R. Hyperkalemia following temporary occlusion of the portal vein and hepatic artery. Britt. J. Surg. 59, No. 2: 125 (Feb. 1972).

54. Barnett, W.D., Turner, M.D., \& Walken, J.W. The effects of afferent circulatory arrest upon hydrogen ion concentration of the liver. Surg. Gynec., Obstet. 106: 511 (1958). 